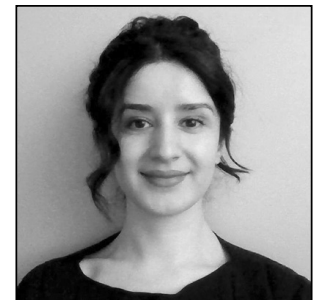

Sevanna Poghosyan

Doctoral student

University of Tartu

\title{
Russian Approaches to the Right of Peoples to Self- Determination: From the 1966 United Nations Covenants to Crimea
}

\section{Introduction}

The 2014 annexation of Crimea and its incorporation into the Russian Federation (RF) marked Russia's departure from its otherwise consistent support for the territorial integrity of states (with the exception of the cases of South Ossetia and Abkhazia). Looking at the Soviet past, one realises that, likewise, the Soviets were flexible in their use and promotion of the notion of self-determination during the de-colonisation era. Through their efforts, a clause on self-determination was included in two major United Nations (UN) treaties: the International Covenant on Economic, Social and Cultural Rights (ICESCR) ${ }^{*}$ and the International Covenant on Civil and Political Rights (ICCPR). ${ }^{{ }_{2}}$ Nevertheless, they refused to acknowledge the existence of similar issues within their territories.

Given the situation outlined above, a research problem can be identified in the contradiction visible in Russia's contemporary approach to the right of peoples to self-determination as manifested in the case of Crimea and its relationship to the Soviet approach to self-determination in the era of de-colonisation. Legal discussion of the subject has generally neglected analysis of the situation in light of the Soviet past, where Russia's current legal thinking is rooted. The objective for this article, therefore, is to fill the gap by looking at Russian theory and practice related to the right of peoples to self-determination from a historical-legal perspective. The article traces the roots of the Soviet approach to self-determination in the 1960 s and that of Russia after the annexation of Crimea, and it articulates the links between the Soviet and the Russian approach to that right. The hypothesis for the study was that the current Russian approach to the right of peoples to self-determination resembles the Soviet one in its legal flexibility characterised by self-interest, hypocrisy, and double standards.

Such analysis is especially topical in that Russia remains involved in several regional secessionist conflicts wherein self-determination is exploited as a key argument for separation, including but not limited

1 International Covenant on Economic, Social and Cultural Rights. New York, 13.12.1966, entering force on 3 January 1979.

2 International Covenant on Civil and Political Rights. New York, 16.12.1966, entering force on 23 March 1976. 
to the cases of Transnistria, South Ossetia, and Abkhazia. ${ }^{*}$ The study employed a legal-historical method to connect the dots between the past and present, with a comparative method utilised for understanding the differences between the Soviet and Western approach and for ascertaining the links between the Soviet and the current Russian approach to self-determination. Moreover, the article presents a summary from analysis of 51 official documents from 2014 to 2020, a corpus reflecting the most relevant speeches and interviews given by Russia's high-ranking officials on justification of Crimea's annexation. The project of analysing the meaning of these political speeches and messages in the context of Russia's international legal framing of the Crimea situation is perhaps the main contribution to the literature and discussion.

\section{From Wilsonian to Bolshevik ideas of self-determination}

Tracing the evolution of self-determination throughout the 2oth century from a vague principle into a firm right in international law reveals three main phases: 1) Wilsonian, 2) de-colonisation, and 3) post-colonial. ${ }^{*}$ Among the figures identified as playing a key role in establishing the liberal-democratic idea of selfdetermination are such thinkers as 'Mill and Mazzini, Wilson and Rousseau'. ${ }^{5}$ The Wilsonian concept of self-determination became a guiding principle during the great powers' negotiations on the future of the erstwhile Austro-Hungarian and Ottoman empires. ${ }^{* 6}$ Nevertheless, it remained a political principle as the clause promising the application of self-determination was ultimately omitted from the final draft of the Covenant of the League of Nations and did not culminate in the development of a general norm of international law at this stage. ${ }^{* 7}$

Alongside Wilson, Lenin was among the earliest proponents of self-determination. Dmitry Baratashvili claimed that Lenin provided the scientific foundation for the link between the democratic world and the recognition of the right of peoples to self-determination. ${ }^{* 8}$ Nevertheless, Lenin's understanding from the very beginning was that, though self-determination entails secession, the ultimate goal was the integration of nations into a socialist world and not their independence. ${ }^{*} 9$ Hence, the Bolshevik party utilised the concept of self-determination for 'the liquidation of capitalism and the construction of socialism'. ${ }^{* 10}$ The Bolsheviks believed that the issue of self-determination was fully resolved within the Soviet Union and that the Union of Soviet Socialist Republics (USSR) was created on a foundation of the voluntary unification of all nations through the exercise of their right to self-determination. ${ }^{* 11}$

The hypocrisy of such thinking was revealed through their practice. For instance, self-determination was cited as a basis for recognising the independence of several states in the 1920-1921 Soviet peace treaties. ${ }^{{ }^{12}}$ In one example, Article 2 of the Tartu Peace Treaty, signed between Soviet Russia and the Republic of Estonia on 2 February 1920, proclaimed the recognition of Estonia's independence on the basis of the right of peoples to self-determination, which granted Estonia the right to secession. ${ }^{*} 13$ Nevertheless, throughout the independent existence of Estonia, the Bolsheviks employed all means at their disposal 'to subvert the

3 Christopher J Borgen, 'Law, Rhetoric, Strategy: Russia and Self-Determination before and after Crimea' (2015) 91 ILS 266.

4 Hurst Hannum, 'Rethinking Self-Determination' (1993) 34(1) VaJIntlL 67.

5 Daniel Philpott, 'In Defense of Self-Determination' (1995) 105(2) Ethics 355. - DOI: https://doi.org/10.1086/293704.

6 Milena Sterio, The Right to Self-Determination under International Law: 'Selfistans', Secession and the Rule of the Great Powers (Routledge 2013) 10. - DOI: https://doi.org/10.4324/9780203083963.

7 Ibid.

8 Dmitrij I Baratashvili, 'Princip ravnopravija i pravo narodov rasporjazhat'sja svoej sud'boj' ['The Principle of Equality and the Right of Peoples To Control Their Own Destiny] in A Nikolaj Ushakov (ed), Konstitucionnye osnovy vneshnej politiki SSSR i mezhdunarodnoe pravo ['Constitutional Foundations of USSR Foreign Policy and International Law'] (Nauka 1985) 202.

9 Lauri Mälksoo, 'The Soviet Approach to the Right of Peoples to Self-Determination: Russia's Farewell to Jus Publicum Europaeum' (2017) 19(2) JHIL 14. - DOI: https://doi.org/10.1163/15718050-19231035.

10 Grigory Tunkin, Theory of International Law (William E Butler tr, Cambridge 1974) 8. - DOI: https://doi.org/10.4159/ harvard.9780674434165.

11 Ibid 10-11.

12 Mälksoo, 'The Soviet Approach to the Right of Peoples to Self-Determination' (n 9) 8.

13 Tartu Peace Treaty, Tartu, 2 November 1920, entering force on 30 March 1920, art 2. 
power in Estonia'.*14 They eventually Sovietised Estonia in line with their approach to Latvia, Lithuania, and Romania's Bessarabia upon conclusion of the Molotov-Ribbentrop pact (on 23 August 1939) and created the appearance of the so-called reunification being entirely voluntary. ${ }^{*} 15$ They refused to admit that in 1940 the Baltic States acceded to the Soviet Union under the pressure of a Soviet ultimatum of 'approval or annihilation'. ${ }^{* 16}$ Moreover, the Soviet authorities fabricated an official narrative according to which they had liberated these states from pro-fascist governments. ${ }^{*} 17$

\section{The USSR and promotion of the right of peoples to self-determination in the era of de-colonisation}

For contextualising the Soviet approach to self-determination in the de-colonisation era, it is important to mention that Marxism, which was the foundation of Soviet legal thinking, saw law as an instrument of the oppression of one social class by another. ${ }^{*} 18$ Moreover, existing legal provisions were subjected to Soviet interpretations, and the Soviets developed a unique, anti-Western understanding of international law. ${ }^{*}{ }^{19} \mathrm{~A}$ kind of thinking wherein the issue of self-determination was resolved in the Soviet Union was crystallised in the de-colonisation era when the USSR took the lead in championing this right at international level. Nevertheless, 'in the Western liberal sense (emphasizing democracy and human rights) there was no "internal self-determination' within the USSR". ${ }^{20}$ Despite this, the USSR started promoting self-determination internationally, casting itself as the original initiator of de-colonisation. ${ }^{*}{ }^{21}$ They were very much successful in this endeavour, partly because, as Dmitry Grushkin has noted, by the end of World War II, the role of the USSR was growing stronger internationally and the voice of the Soviets mattered more than ever before. ${ }^{* 22}$ Soviet legal scholar Grigory Tunkin, for example, argued that self-determination became a recognised principle of international law through the 'persistent struggle of the Soviet Union and other progressive forces'. ${ }^{23}$ Eventually, an article on self-determination was included in the UN Charter, in line with the proposal of the Soviet delegation. ${ }^{*} 24$ In the eyes of Soviet legal scholar Igor Blishchenko, this exemplified the triumph of the USSR against the colonial system of imperialism. ${ }^{*} 5$ Later, the Soviets insisted on inclusion of self-determination in the 1948 Universal Declaration of Human Rights also; however, this was prevented by the Western colonial powers, who argued that the principle would pose a danger to public order and the interests of other states. ${ }^{*} 6$

The Soviets nevertheless managed to continue their promotion of a self-determination agenda and played a decisive role in drafting the two major UN General Assembly (UNGA) resolutions on de-colonisation. ${ }^{*} 27$ These were the Declaration on the Granting of Independence to Colonial Countries and Peoples,

14 Silvia P Forgus, 'Soviet Subversive Activities in Independent Estonia (1918-1940)' (1992) 23(1) JBS 29. - DOI: https:// doi.org/10.1080/01629779100000261.

15 Mälksoo, 'The Soviet Approach to the Right of Peoples to Self-Determination' (n 9) 12-13.

16 Antonio Cassese, Self-Determination of Peoples: A Legal Reappraisal (CUP 1995) 258.

17 David Kirby, 'Incorporation: The Molotov-Ribbentrop Pact' in Graham Smith (ed), The Baltic States (Palgrave Macmillan 1996) 77. - DOI: https://doi.org/10.1007/978-1-349-14150-0_4.

18 Anna Isaeva, 'Contradictions and Incompleteness in Russian Legal Discourses' in Sean P Morris (ed), Russian Discourses on International Law (Routledge 2019) 31. - DOI: https://doi.org/10.4324/9781315123837-3.

19 Lauri Mälksoo, 'Russian Approaches to International Law' (OUP 2015) 4.

20 Mälksoo, 'The Soviet Approach to the Right of Peoples to Self-Determination' (n 9) 17.

21 Tero Lundstedt, 'The Changing Nature of the Contemporary Russian Interpretation of the Right to Self-Determination under International Law' in Sean P Morris (ed), Russian Discourses on International Law (Routledge 2019) 197-99. - DOI: https://doi.org/10.4324/9781315123837-10.

22 Dmitry Grushkin, Pravo Narodov Na Samoopredelenie: Ideologija i Praktika ['The Right of Peoples to Self-Determination: Ideology and Practice'] (Zven'ja 1970) 8.

23 Tunkin (n 10) 61.

24 Lundstedt (n 21) 202.

25 As cited by Bill Bowring, Law, Rights and Ideology in Russia: Landmarks in the Destiny of a Great Power (Routledge 2013) 85. - DOI: https://doi.org/10.4324/9780203490211.

26 Tunkin (n 10) 64.

27 Ibid. 
adopted via UNGA resolution $1514^{* 28}$, and resolution $1541{ }^{*}{ }^{* 2}$ This accomplishment was accompanied by the so-called Salt Water Thesis, which stipulated that self-determination may be invoked only by those territories that are geographically separate from the colonising power, or the ones divided from it by blue water. ${ }^{*} 30$ This favoured the Soviets greatly, as it meant that self-determination would not be exercised in opposition to their interests.

As the project continued, a critical point for the advancement of self-determination as a right in international law was the inclusion of a relevant provision in the $1966 \mathrm{UN}$ treaties, the ICESCR and ICCPR. ${ }^{*} 31$ Before this, the Soviets maintained their insistence that self-determination had already been fully expressed in the USSR and criticised Western European powers for their imperial and colonial realities, all the while objecting to any similar criticism levelled at themselves. ${ }^{*} 32$ The Western states, for their part, opposed any provision for self-determination as they pursued their colonial interests, but they did eventually acknowledge the possibility of secession in the colonial context. ${ }^{*} 33$ The prevailing understanding was that, while the covenants entailed non-colonised peoples' entitlement to a form of internal governance within their mother state, these peoples did not acquire a right to seek independence. ${ }^{*}{ }^{4}$ Colonised peoples were understood to be granted the right to freely decide their international status and determine their political fate. ${ }^{*} 35$

The main objection to the inclusion of a clause on self-determination in the twin covenants had to do with hypocrisy: these would not apply to the people within the USSR and had been applied only to Finland in the former Tsarist Empire. ${ }^{*} 6$ Blishchenko's counter to this argument was the statement that within the USSR the republics enjoyed autonomy. ${ }^{*}{ }^{37}$ Nevertheless, as scholar Bill Bowring noted, Blishchenko failed to mention the cases in which the Soviets resorted to force or threat of force to coerce certain nations to join the Soviet Union. ${ }^{*} 38$ The notion that self-determination was fully actualised within the USSR was articulated also by Baratashvili, who argued that the resolution of the question of nationalities within the USSR was among the greatest achievements of socialism. ${ }^{*} 39$ Meanwhile, the Soviets once again called their commitment to self-determination into question with the 1969 military invasion of Czechoslovakia ${ }^{* 0}$, which has been characterised as directing 'highly intense coercion against the territorial integrity and political independence of Czechoslovakia'. ${ }^{41}$ For justification, they produced an unsigned document implying that Czech leaders had 'invited' the Warsaw Pact forces to enter Czechoslovakia. ${ }^{*}{ }^{2}$

\section{The right of peoples to self-determination in the post-colonial era}

To understand the contradictions found in Russia's approach to self-determination in our times, it is important to identify the position of international law on self-determination in the post-colonial era. One document that encapsulates these developments is the Declaration on Principles of International Law Concerning

28 Declaration on the Granting of Independence to Colonial Countries and Peoples, UN General Assembly A/RES/1514(XV), adopted 14 December 1960, art 2.

29 Addressing principles that should guide members in determining whether or not an obligation exists to transmit the information called for under Article 73e of the UN Charter, UN General Assembly A/RES/1541, adopted on 15 December 1960.

30 Jeff Corntassel, 'Toward Sustainable Self-Determination: Rethinking the Contemporary Indigenous-Rights Discourse' (2008) 33(1) Alternatives 108. - DOI: https://doi.org/10.1177/030437540803300106.

31 ICCPR (n 2); ICESCR (n 1).

32 Mälksoo, 'The Soviet Approach to the Right of Peoples to Self-Determination' (n 8) 16.

33 Helen Quane, ‘The United Nations and the Evolving Right to Self-Determination' (1998) 47(3) ICLQ 543. - DOI: https:// doi.org/10.1017/s0020589300062175.

34 Sterio (n 6) 11.

35 Ibid 11.

36 As cited by Bowring (n 25) 84.

37 Ibid.

38 Ibid.

39 Baratashvili (n 8) 205.

40 David W Paul, 'Soviet Foreign Policy and the Invasion of Czechoslovakia: A Theory and a Case Study' (1971) 15(2) ISQ 178. - DOI: https://doi.org/10.2307/3013548.

41 Richard M Goodman, 'The Invasion of Czechoslovakia: 1968' [1969](4) Int Lawyer 57.

42 Ibid 44. 
Friendly Relations and Co-operation among States, or FRD. ${ }^{*} 43$ Inter alia, the FRD criticises directing the use of force against the exercise of the right to self-determination; nevertheless, it also prioritises the principle of the territorial integrity of states. ${ }^{*} 44$ Meanwhile, the inverted reading of the safeguard clause of the FRD gave rise to the theory of 'remedial secession'. ${ }^{*} 45$ The proponents of this theory assume the possibility of secession for a group of people in exceptional circumstances in the event that multiple grievances are present, though the theoretical and practical foundations for such a theory are, in reality, very weak. ${ }^{*} 46$

Furthermore, a provision for self-determination had been included in the Helsinki Final Act in $1975 .{ }^{*} 47$ That said, it must be read in the context of the principles of the inviolability of frontiers and the territorial integrity of states. ${ }^{*} 48$ The latter view was later confirmed in the 1990 Paris Charter. ${ }^{*} 49$ Finally, the reluctance to accept secession outside the de-colonisation context was reflected also in the context of discussions of the right of indigenous peoples to self-determination, which eventually resulted in the adoption of the 2007 UNGA Declaration on the Rights of Indigenous Peoples. ${ }^{*} 50$

Overall, throughout its development, the concept of the right of self-determination has been at constant odds with the principle of territorial integrity of states, which lies at the core of the contemporary international legal system and is rooted in the doctrines of uti possidetis juris and terra nullius. ${ }^{*}{ }^{11}$ The clash between self-determination and territorial integrity is significant in the case of external self-determination - i.e. secession. States traditionally disapprove of secession because encouragement of territorial separation is perceived to be dangerous. ${ }^{*} 2$ While secession is not a recognised right in international law, it is not prohibited either. ${ }^{*} 33$ Secession is regulated by the legal provisions for self-determination and territorial integrity. International law does not prohibit consensual secession as long as it is exercised under constitutional processes. ${ }^{*} 54$ As for unilateral secession, it is allowed only in the context of de-colonisation and arguably in the case of reclaiming a territory subject to unjust military occupation. ${ }^{*} 55 \mathrm{All}$ in all, in the post-colonial era, the dominant understanding is that self-determination is a procedural right that may not amount to a right to internal or external self-determination. ${ }^{*}{ }^{56}$

\section{Russia's approach to the right of peoples to self- determination before the annexation of Crimea}

If one is to understand the relationship between Russia's approach to self-determination in the case of Crimea and the Soviet approach in the de-colonisation era, it is vital to establish the links between Russian and Soviet legal thinking. After the collapse of the Soviet Union, Russia pledged to maintain legal continuity with the Soviet Union, inheriting its rights and obligations in line with the doctrine of state

43 Declaration on Principles of International Law concerning Friendly Relations and Co-operation among States in accordance with the Charter of the United Nations UN General Assembly A/RES/26/25 (XXV). 24.11.1970.

44 Ibid.

45 For more details on remedial secession theory, see Allen Buchanan, 'Justice, Legitimacy, and Self-Determination: Moral Foundations for International Law' (OUP 2004). - DOI: https://doi.org/10.1093/0198295359.003.0001; James Summers, 'Relativizing Sovereignty: Remedial Secession and Humanitarian Intervention in International Law' (2010) 1 STAIR; Jure Vidmar, 'Remedial Secession in International Law: Theory and (Lack of) Practice' (2010) 6(1) STAIR 2010.

46 Vidmar (n 45) 50.

47 Final Act of Helsinki, Organization for Security and Co-operation in Europe (Conference on Security and Co-operation in Europe, 1 August 1975).

48 Hannum (n 4) 29.

49 Charter of Paris for a New Europe (Conference on Security and Co-operation in Europe, Paris, 21 November 1990) 5.

50 Declaration on the Rights of Indigenous Peoples, UN General Assembly A/RES/61/295, adopted 2 October 2007.

51 Joshua Castellino, 'Territorial Integrity and the Right to Self-Determination: An Examination of the Conceptual Tools' (2008) 33 Brook J Intl L 520.

52 Vend P Nanda, 'Self-Determination under International Law: Validity of Claims to Secede' (1981) 13(2) Case W Res J Intl L 264.

53 Hannum (n 4) 42.

54 Buchanan (n 45) 338.

55 Ibid 333.

56 Jan Klabbers, 'The Right To Be Taken Seriously: Self-Determination in International Law' (2006) 28(1) HRQ 189. - DOI: https://doi.org/10.1353/hrq.2006.0007. 
continuity. ${ }^{*}{ }^{57}$ Moreover, it retained the Soviet federal formula and understanding of self-determination, hence deeming the issue of self-determination resolved within the federation and applicable only to other states. ${ }^{*}{ }^{58}$ Although Russia abandoned Soviet ideology in favour of capitalist fundaments, ${ }^{*} 59$ the ghost of Soviet legal thinking could not be exorcised from the post-Soviet space immediately. ${ }^{*}{ }^{60}$ Russian doctrine was not submitted to dialogue in which Western discourse was granted equal footing, so it remained shielded from the latter influence. ${ }^{*}{ }^{* 1}$ Also, current Russian legal doctrine suffers in general from disregard for fundamental theoretical issues related to the history of international law and self-determination. ${ }^{* 62}$ Accordingly, Russia's current approach to self-determination remains firmly rooted in Soviet legal thought.

The overall picture that emerges is that in 1991-2013 Russia maintained strong opposition to recognising self-determination outside the colonial context. ${ }^{*} 63$ In the 1990 s, its main concern was secessionist aspirations of nationalities within its territories, Chechnya in particular. ${ }^{*}{ }^{6}$ Eventually, the Russian Constitutional Court reiterated the longstanding position in two major decisions, pertaining to Tatarstan and Chechnya, by ruling against the possibility of secession. ${ }^{* 6}$

The situation changed over time, in line with major geopolitical disruptions in the region. The 1990 and early 2000 s were significant for institution-building and expansion in the West, which Russia perceived as a threat. ${ }^{* 66}$ It is against the backdrop of these developments that the secessionist conflict escalated in Kosovo in 1999. This was followed by a NATO intervention that led to deterioration in relations between Russia and the West. ${ }^{* 67}$ Upon Kosovo's 2008 declaration of independence, Russia, in its written submission to the International Court of Justice in the Kosovo proceedings, explicitly argued against the possibility of legitimate secession based on secession in fact, though this occasion did mark the first time Russia made reference to the argument of remedial secession. ${ }^{*} 68$ Even though Russia did not accept the possibility of remedial secession for Kosovo, it did imply that secession is possible in general, albeit under highly specific conditions. ${ }^{*} 69$ Meanwhile, the years since Russia's invasion of Georgia in 2008 witnessed a significant shift from arguments based on territorial integrity to ones related to the protection of co-nationals or co-ethnics. ${ }^{*} 70$

\section{Russia's approach to self-determination after the 2014 annexation}

\subsection{Background on the annexation of Crimea}

The annexation of Crimea in 2014 followed a series of events that Russia perceived as a threat directed against its various positions in its so-called sphere of influence. Specifically, Ukraine's attempt to sign an Association Agreement with the EU was anything but acceptable to Russia. Moscow believed that inciting a dispute framed as one of self-determination would hinder Ukraine's integration into Europe. ${ }^{* 71}$ Russia annexed Crimea in March 2014. Among the events following this act were armed intervention by Russian

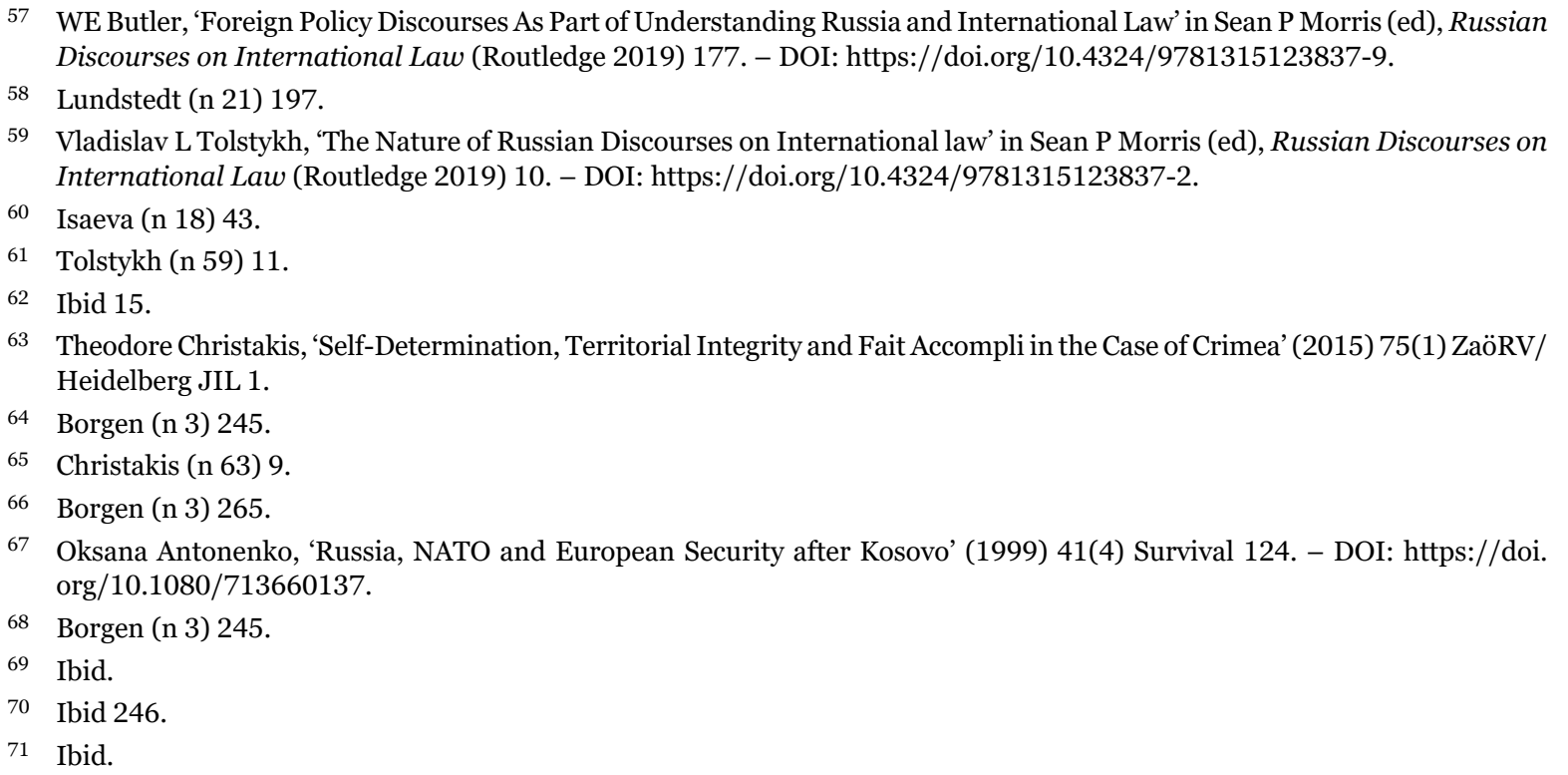


forces in the form of 'little green men,, ${ }^{*} 2$ a referendum, and a declaration of Crimean independence. ${ }^{*} 73$ According to the officially reported results, $96.77 \%$ voted for unification with the RF. ${ }^{*} 4$

After the referendum, Russia's President Putin signed an executive order to recognise Crimea, and, once the relevant bodies had been informed that local Crimean institutions had proposed joining the $\mathrm{RF}$, the agreement on incorporation of the Republic of Crimea into the RF was signed. In the meantime, Ukraine's Constitutional Court stated that such a change in territory would be possible only upon a countrywide Ukrainian referendum and that only Ukraine's parliament possessed the authority to call for such a referendum. Consequently, the Constitutional Court mandated that the Crimean authorities repeal the referendum decree. Clearly, the Crimea case revolved around the complexities of violations of domestic and international legal norms. ${ }^{*} 75$

\subsection{Critical analysis of Russia's arguments pertaining to a Crimean right to self-determination}

Russia followed its annexation of Crimea by embarking on legitimising Crimea's cause for self-determination, with utmost confidence. The general line of Russia's argumentation is expressed in the 18 March 2014 address of President Putin. ${ }^{*} 76$ Analysis of a corpus of 51 official documents identified Russia's justification narratives as including both legal and non-legal arguments. The arguments fall into two main classes: issues related to self-determination and secession (referendum, Ukrainian violations of human rights, the Kosovo precedent, and self-determination) and other arguments (political crisis in Ukraine, Crimea after 2014, the West being to blame, Crimea's history, and protecting compatriots).

\subsubsection{Arguments related to self-determination and secession}

Self-determination: Representing the annexation of Crimea as a case of self-determination was important for Russia. Illustrating this, Russia's foreign minister, Sergei Lavrov, claimed that during the Cold War the two opposing blocs had agreed on the principles enshrined in the Final Act, emphasising 'respect for people's right to self-determination [and] respect for the sovereignty and territorial integrity of states'. ${ }^{*} 77$ Furthermore, Russia's ambassador to Indonesia at the time argued that the realisation of self-determination by Crimeans was achieved per Article 1 of the UN Charter. ${ }^{*} 8$ At the same time, while discussion of self-determination continued in the post-colonial era, there is still not enough support for expression of secession outside the decolonisation context. While there is support for its validity in the context of decolonisation, Crimea falls outside that context. Interesting references to sovereignty and territorial integrity were made elsewhere. Putin's interpretation of sovereignty is noteworthy in that he claimed: '[I]f a country opts for this and wants to cede part of its sovereignty, it's free to do so. [...] [I]f Ukraine joins, say, NATO, NATO's infrastructure will move directly toward the Russian border, which cannot leave us

72 Shane Reeves \& David A Wallace, 'The Combatant Status of the 'Little Green Men' and Other Participants in the Ukraine Conflict' (2015) 91 Int Law Stud 393.

73 Thomas D Grant, 'Annexation of Crimea' (2015) 109(1) AJIL 68. - DOI: https://doi.org/10.5305/amerjintelaw.109.1.0068.

74 Ibid 69.

75 Ibid 69-71.

76 'Obrashhenie Prezidenta Rossijskoj Federacii. Oficial'nye setevye resursy Prezidenta Rossii’ ['The Address of the President of the Russian Federation: Official Internet Resources of the President of Russia'] (18 March 2014) <http://kremlin.ru/ events/president/news/20603> accessed 10 February 2020. All translations from Russian into English are by the author of this article unless otherwise indicated.

77 Interview with Foreign Minister Sergey Lavrov for the Russiya-1 TV television programme An Evening with Vladimir Solovyov (Embassy of the Russian Federation to the UK, 25 December 2014). See <www.rusemb.org.uk/foreignpolicy/2864> accessed 10 February 2020.

78 'Vystuplenie Posla Rossijskoj Federacii v Indonezii M.Ju.Galuzina v Universitete Indonezii na seminare 'Krizis na Ukraine i ego vlijanie na Jugo-Vostochnuju Aziju', g. Depok, 29 aprelja 2014 goda, MID Rossijskoj Federacii' ['Speech of Ambassador of the Russian Federation to Indonesia MY Galuzin at the University of Indonesia's Seminar 'The Crisis in Ukraine and Its Impact on South-East Asia', Depok, 29 April 2014, Ministry of Foreign Affairs of the Russian Federation (MID)'] (15 May 2014) <www.mid.ru/web/guest/maps/id/-/asset_publisher/zaMdV5V4XUmC/content/id/60258> accessed 8 February 2020. 
indifferent. ${ }^{*} 79$ Thus, Russia's sovereignty was aggrandised and construed to be more important than that of Ukraine.

Referendum: Russian officials often argued that the unification of Crimea with Russia took place after the Crimeans opted for self-determination via a referendum by an overwhelming majority. ${ }^{*} 0$ In reality, the way the referendum in Crimea was held attracted widespread criticism, as it was organised in a manner that pointed to a predetermined result. ${ }^{*}{ }^{1}$ In any case, international law does not confer any special status on referenda; neither has a role for them been supported by the international community in the absence of backing from the parent state. ${ }^{*} 2$ In the case of Crimea, only the Ukrainian Constitution could confer a right on Crimea to decide its political future by referendum. ${ }^{*} 83$ In addition, the referendum was preceded by use (or at least threat of use) of military force by Russia. ${ }^{*} 84$

Ukraine's violations of human rights: Russian officials argued that the decisions of those behind the coup ran counter to the interests of the Russian-speaking population of Ukraine. ${ }^{*} 5$ Special emphasis was given to the elimination of the official status of the Russian language. ${ }^{*} 86$ While there is no denying that there have been human-rights violations in Ukraine-specifically targeting the Tatar minority-these violations were not grave and systemic. ${ }^{*} 87$ In the wake of the Soviet Union's dissolution, ethnic Russian were not subjected to assimilation and the Russian language has been used to a large extent in Ukraine as a second language. ${ }^{*} 8$ This theme is particularly interesting in light of the grim human-rights situation in Russia itself, which has been well-documented throughout recent decades. ${ }^{*} 89$ This makes Russia's concerns about Ukraine's violations of human rights hypocritical. Also, the theme of human-rights violations is closely linked to the remedial secession theory, which is widely contested. Finally, even if Ukraine had violated the human rights of Crimeans and even if secession were possible from the perspective of the remedial secession theory, secession would still be understood only as a remedy of last resort, pursued only after all other efforts are proven fruitless. ${ }^{*} 90$ In contrast, no attempts were made to resolve the crisis in Crimea in good faith. That is, as others have noted, 'even if a problem had existed in Crimea of a type justifying remedial secession, the situation was not ripe for secession in March 2014,. ${ }^{91}$

The Kosovo precedent: With another line of argument, despite opposing the independence of Kosovo, Russia went on instrumentalising the Kosovo case for its interests. ${ }^{*} 92$ For example, Russian officials argued that the advisory opinion of the International Court of Justice on Kosovo declared that there had been no violation of international law when the region was separated from its parent state. ${ }^{*}{ }^{9}$ In this

79 Interview of Vladimir Putin with Radio Europe 1 and the TV channel TF1 (from Official Internet Resources of the President of Russia, 4 June 2014) <http://en.kremlin.ru/events/president/news/45832> accessed 9 February 2020.

80 'Interv'ju Posla Rossii v Makedonii O.N.Shherbaka zhurnalu 'Kapital' 5 ijunja 2014 goda. MID Rossijskoj Federacii' ['Interview of Russia's Ambassador to Macedonia, ON Shcherbak, with Capital Magazine on 5 June 2014, MID'] (6 June 2014) <www. mid.ru/web/guest/maps/mk/-/asset_publisher/Bx1lWHr8ws3J/content/id/56878> accessed 8 February 2020.

81 Vasile Rotaru \& Miruna Troncotă, 'Continuity and Change in Instrumentalizing 'the Precedent': How Russia Uses Kosovo To Legitimize the Annexation of Crimea' (2017) 17(3) J Southeast Eur Black Sea Stud 13. - DOI: https://doi.org/10.1080 /14683857.2017.1348044

82 Borgen (n 3) 249.

83 Ibid.

84 For more details on the questions related to the use of force and Crimea, see Grant (n 73) 77-87.

85 'Interv'ju Posla Rossii v Shvecii V.I.Tatarinceva «Krym vsegda prinadlezhal Rossii», opublikovannoe v gazete «Aftonbladet» 20 ijulja 2014 goda. MID Rossijskoj Federacii' [Interview of the Ambassador of Russia to Sweden V.I. Tatarintsev 'Crimea has always belonged to Russia', published in the newspaper 'Aftonbladet' on July 20, 2014, (MID)] (22 July 2020) <www. mid.ru/web/guest/maps/se/-/asset_publisher/Nr26tJIotl7z/content/id/677071> accessed 9 February 2020.

86 'Vystuplenie Postojannogo predstavitelja Rossii pri OON V.I.Churkina na zasedanii General'noj Assamblei OON, N'ju-Jork, 27 marta 2014 goda. MID Rossijskoj Federacii' ['Statement by VI Churkin, Permanent Representative of Russia to the UN, at a Meeting of the UN General Assembly, New York, 27 March 2014'] (MID) (27 March 2014) <www.mid.ru/web/guest/ general_assembly/-/asset_publisher/lrzZMhfoyRUj/content/id/68754> accessed 9 February 2020.

87 Grant (n 73) 74

88 Ibid.

89 Halya Coynash \& Austin Charron, 'Russian-occupied Crimea and the State of Exception: Repression, Persecution, and Human Rights Violations’ (2019) 60(1) Eurasian Geogr Econ 28-53. - DOI: https://doi.org/10.1080/15387216.2019.1625279.

90 Grant (n 73) 76.

91 Ibid 77.

92 Interview with Vladimir Putin for the German television channel ARD (from Official Internet Resources of the President of Russia 17 May 2014) <http://en.kremlin.ru/events/president/news/47029> accessed 9 February 2020.

93 'Vystuplenie Posla Rossijskoj Federacii v Indonezii M.Ju.Galuzina' (n 78). 
context, the most important point is that, after having opposed recognition of Kosovo's independence and having blamed the Western states for opening a Pandora's box of secessionist movements, Russia employed the same argument to justify the annexation of Crimea, in a way contradicting its previous words and actions. The general understanding is that the grounds for equating the cases of Kosovo and Crimea are very weak. ${ }^{*} 94$

\subsubsection{Other arguments}

\section{Political crisis in Ukraine, blaming the West, and protecting compatriots}

Featuring in the recurring themes were portrayal of the political crisis in Ukraine as a direct threat to the country's Russian-speaking population in general and Crimea in particular. Specifically, the main argument was that, in light of the 'changing political situation, which threatened violation of the rights and freedoms of people', the people of Crimea had no alternative to secession. ${ }^{*} 95$ Furthermore, the attempt of the EU to sign an Association Agreement with Ukraine was deemed unacceptable for Russia ${ }^{*}{ }^{* 6}$, in addition to which Russia saw the political crisis as manufactured by the West to destabilise the region. ${ }^{*} 97$ In this light, Russia constructed itself as a defender of the Russian-speaking population in Ukraine. ${ }^{*} 98$

From the perspective of international law, however, the political crisis in Ukraine did not authorise Russia to interfere in the affairs of the country or annex its territories. Although international law's prohibition of the use of force is not absolute and Article 51 of the UN Charter does specify that it is permitted for reasons of self-defence if an armed attack is perpetrated against a member of the UN" ${ }^{*}$, scholars conclude that 'the prohibition against acquisition of territory by threat or use of force [...] is not subject to qualification,. ${ }^{* 100}$ This principle is reflected in the 1974 UNGA Definition of Aggression ${ }^{*}{ }^{* 101}$ and renders Russia's claimed justifications for the annexation of Crimea void - as scholars conclude 'justifications for an armed intervention, even if accepted, are not justifications for the forcible acquisition of territory'."102 Also invalid is Russia's attempt to argue the invasion's legality on the basis of an invitation from Victor Yanukovych. ${ }^{* 103}$ While a state may invite another state to render assistance, the consent of the inviting state must be clear. In the Crimea case, in contrast, the validity of the invitation by Yanukovych was widely contested. ${ }^{*} 104$

94 The validity of the Kosovo/Crimea parallel has been discussed in depth by Rotaru and Troncotă (n 81).

95 'Interv'ju Posla Rossii v Litve A.I.Udal'cova gazete 'Respublika', 3 janvarja 2015 goda, MID Rossijskoj Federacii' ['Interview of Ambassador of Russia to Lithuania AI Udaltsov with the Newspaper Republic, MID'] (13 January 2015) <www.mid.ru/ web/guest/maps/lt/-/asset_publisher/ePq2JfSAWgY2/content/id/1547665> accessed 14 February 2020.

96 'Poslanie Prezidenta Rossijskoj Federacii V.V.Putina Federal'nomu Sobraniju, Moskva, Kreml', 4 dekabrja 2014 goda, MID Rossijskoj Federacii' ['Annual Address of Vladimir Putin, President of the Russian Federation, to the Federal Assembly, Moscow, the Kremlin, 4 December 2014, MID'] (4 December 2014) <www.mid.ru/web/guest/foreign_policy/news/-/ asset_publisher/cKNonkJE02Bw/content/id/807311> accessed 14 February 2020.

97 'Interv'ju Ministra inostrannyh del Rossii S.V.Lavrova programme «Voskresnoe vremja», Moskva, 30 marta 2014 goda. MID Rossijskoj Federacii' ['Interview of Russian Minister of Foreign Affairs Sergey Lavrov for the Programme Sunday Time, Moscow, 30 March 2014, MID'] (30 March 2014) <www.mid.ru/web/guest/foreign_policy/news/-/asset_publisher/ cKNonkJE02Bw/content/id/68426> accessed 8 February 2020.

98 'Interv’ju Posla Rossii v Italii S.S.Razova dlja radioprogrammy “Corriere diplomatico” gosteleradio Italii “RAI Radio 1”, 19 ijunja 2014 goda, MID Rossijskoj Federacii' ['Interview of Russia's Ambassador to Italy SS Razov for the Radio Programme Corriere Diplomatico, by Italian State Radio and Television Outlet RAI Radio 1, 19 June 2014, MID'] (23 June 2014) <www. russia.org.cn/ru/news/intervyu-posla-rossii-v-italii-s-s-razova-dlya-radioprogrammy-corriere-diplomatico-gosteleradioitalii-rai-radio-1/> accessed 8 February 2020.

99 Charter of the United Nations, San Francisco, 26 June 1945, entering force on 24 October 1945, art 51.

100 Grant (n 73) 77.

101 Definition of Aggression, UN General Assembly A/RES/3314, 14.12.1974, art 5, para 3.

102 Grant (n 73) 77.

103 Ibid 83.

104 Ibid. 


\section{Revisionist history and Crimea after 2014}

Most of the Russian documents discussing the Crimea case depict the intervention as righting historical wrongs, with claims that 'in 2014, historical justice triumphed" ${ }^{* 05}$. That is, 'Khrushchev's historical mistakes and voluntarism were corrected without a single shot or sacrifice ${ }^{, * 106}$ in the transfer of Crimea from Russia to Ukraine in 1954. Some officials even reached as far back as the 19th century, to argue that Crimea has always been Russian. ${ }^{* 107}$ Moreover, to rationalise the reunification of Crimea as the right decision, Russian officials claimed that Crimea's situation had improved in the wake of incorporation into Russia. ${ }^{*} 108$ The historical arguments are problematic, given the risks connected with the clash between subjective and instrumentalist interpretations of the situation, put forth by different actors. ${ }^{*} 109$ Were history valid justification, then Russia should have been reminded that the Russian Empire 'conquered Crimea from the Ottoman Empire or that the Tatar Khanate had a longer history in Crimea than Russia'. ${ }^{* 110}$

Overall, Russia's attempt to exploit legally and extralegally grounded arguments to present the annexation of Crimea as a case of self-determination was not straightforward, because it proceeded from flawed legal foundations.

\section{Conclusion}

The discussion here illustrates that, even in the earliest stages of the concept's development, the Bolshevik and the Wilsonian ideas of self-determination diverged: the former was based on socialism, and the latter was grounded in liberal-democratic thought. While the Soviets were the first to bring the principle into bilateral international treaties, in practice they tried to reclaim the territories of the Russian Empire. Here, hypocrisy flourished in the gap between theory and practice. The West at least was up-front and consistent in its refusal to accept the possibility of national minorities' secession for reason of self-determination, thus displaying less hypocrisy. Furthermore, during the era of de-colonisation the Soviets held that the issue of self-determination was resolved within their territories, with self-determination being for victims of colonialism. While the Western states too were hypocritical, prioritising their own interests while giving lip service in other directions, they were unlike Russia in that they did not propose and push for such legal standards as they would not be able/willing to uphold.

With the transition from the Soviet Union, Russia, just as the Soviet Union had, deemed the issue of self-determination resolved within the frames of federalism; however, the situation in Chechnya and in Tatarstan, for example, posed serious challenges to this kind of thinking. Throughout 1991-2013, Russia strongly opposed interpreting self-determination as valid outside a colonial context. However, after Kosovo's declaration of independence, Russia started gradually allowing for the possibility of secession beyond such a context. The fact that, exactly as the Soviets had, Russia perceived the issue of self-determination to be resolved within its territory, gave Russia the confidence to criticise Western actions in Kosovo and later argue for a Crimea's right to self-determination.

As for the resonance between the Soviet and Russian approach to self-determination, several patterns were identified. In the case of Crimea, Russia appealed to self-determination for territorial expansion, which

105 'Vystuplenie Postojannogo predstavitelja Rossii pri OON V.I.Churkina' (n 86).

106 'Interv'ju Posla Rossii v Indii A.M.Kadakina gazete «The Hindu», opublikovannoe 21 ijulja 2014 goda, MID Rossijskoj Federacii' ['Interview with Russia's Ambassador to India A Kadakin for The Hindu, published on 21 July 2014, MID'] (25 May 2014) <https://www.mid.ru/web/guest/maps/in/-/asset_publisher/EpJ5G4lcymvb/content/id/676722> accessed 15 February 2020.

107 'Pis'mo Posla Rossii v Kazahstane M.N.Bocharnikova v otvet na interv'ju i kommentarii posla Velikobritanii v Kazahstane, MID Rossijskoj Federacii' ['Letter from Russia's Ambassador to Kazakhstan MN Bocharnikov in Response to Interviews and Comments from the British Ambassador to Kazakhstan, MID'] (3 April 2015) <www.mid.ru/web/guest/maps/kz/-/ asset_publisher/44tjMzWwjAFr/content/id/1528340> accessed 14 February 2020.

108 'Interv'ju Posla Rossii v Albanii A.R.Karpushina albanskomu telekanalu 'ABC News', Tirana, 16 sentjabrja 2017 g, MID Rossijskoj Federacii 2017' ['Interview of Russia's Ambassador to Albania AR Karpushin for the Albanian TV Channel 'ABC News', Tirana, 16 September 2017, MID’] (18 September 2017) <www.mid.ru/web/guest/maps/al/-/asset_publisher/ U6lx5jp8oEzV/content/id/2864874> accessed 12 February 2020.

109 Rotaru \& Troncotă (n 81) 13.

110 Ibid. 
reflected Russian anxiety in response to EU/NATO eastward expansion. Thus, Russia, just as the Soviets did, instrumentalised self-determination in line with its self-interest. Furthermore, in a similarity to the Soviet approach visible in the era of de-colonisation, the case of Crimea showed Russia resorting to double standards by contending that the issue of self-determination was resolved in Russia and that Ukraine, not Russia, had issues with self-determination. Most likely, Russia would not show the same confidence were Chechnya and Tatarstan to revive their secessionist aspirations.

Additionally, the study revealed that Russia tried to justify its acts in Ukraine with the language of international law. Among other things, Russia invoked a claimed invitation by Yanukovych as legal grounds for intervention. This was contested by the international community. It was in the same style that the Soviets had intervened in Czechoslovakia and, as justification, produced the unsigned document implying that Czech leaders had invited the Warsaw Pact forces in. Earlier, the Soviets had refused to admit that the Baltic States had acceded to the Soviet Union in 1940 only under the threat of force, with a fabricated narrative of liberation. In these cases, coercion was applied against other states' territorial integrity and political independence. This was far out of line with the Western understanding of self-determination.

Given what is outlined above, there is support for the hypothesis that the Russian approach to the right of peoples to self-determination in the case of Crimea resembles the Soviet approach in its legal flexibility expressing self-interest, hypocrisy, and double standards. For Russia and the Soviet Union both, the main point of departure was the perception of possessing greatness, power, and sovereignty that merit precedence over other states'. In both cases, the prevailing thinking was that the issue of self-determination was resolved within the territories of the nation (whether the USSR or the RF) and that it was only other states that had problems in this regard. Hence, both situations implied double standards domestically and internationally.

Thus, one can conclude that, with the annexation of Crimea, Russia, similarly to the Soviet Union, started putting forth significant challenges to the universality of international law on self-determination. Nevertheless, caution is warranted with regard to the question of whether Russia has laid claim to a unique anti-Western approach to international law or not. Arguably, seven years is not enough time for clarifying such inferences. Finally, the findings from the study demonstrate that the historical perspective derived from comparative analysis considering the Soviet approach reveals nuances that otherwise are hard to spot. Hence, renewed discussion of the influence of Soviet international legal thinking on that of contemporary Russia is clearly warranted. 